\title{
Incidence, Awareness, and Reporting of Sport-Related Concussions in Manitoba High Schools
}

\author{
Glen L. Bergeron
}

\begin{abstract}
Background and Objectives: Federal and provincial governments in Canada are promoting provincial legislation to prevent and manage sport-related concussions (SRCs). The objective of this research was to determine the incidence of concussions in high school sport, the knowledge of the signs, symptoms, and consequences of SRC, and how likely student athletes are to report a concussion. Methods: A cross-sectional survey of athletes $(N=225)$ from multiple sports in five high schools in one Manitoba school division was conducted. Results: Participants in this study were well aware of the signs, symptoms, and consequences of SRC. Cognitive and emotional symptoms were the least recognized consequences. SRC is prevalent in high schools in both males and females across all sports. Of the 225 respondents, 35.3\% reported having sustained an SRC. Less than half (45.5\%) reported their concussion. Athletes purposely chose not to report a concussion in games $(38.4 \%)$ and practices $(33.8 \%)$. Two major barriers to reporting were feeling embarrassed (3.4/7) and finding it difficult (3.5/7) to report. There was, however, strong agreement (Mean 5.91/7, SD 0.09) when asked if they intend to report a concussion should they experience one in the future. Conclusions: The results suggest that high school athletes would benefit from more SRC education. Coaches and team medical staff must be trained to be vigilant for the mechanism, signs, and symptoms of injury in both game and practice situations. This study will also inform the implementation of pending legislation in Manitoba and perhaps other provinces in Canada.
\end{abstract}

RÉSUMÉ: Fréquence, prise de conscience et signalement des commotions cérébrales liées au sport dans les écoles secondaires du Manitoba. Contexte et objectifs : Au Canada, tant le gouvernement fédéral que les gouvernements des provinces cherchent à encourager l'adoption de lois provinciales visant à prévenir et à prendre en charge les commotions cérébrales liées au sport. L'objectif de cette étude a été de déterminer la fréquence de commotions cérébrales en lien avec la pratique sportive dans les écoles secondaires, de dresser un état des connaissances en lien avec les signes, les symptômes et les conséquences de ce type de traumatisme et de calculer la probabilité que des athlètes étudiants le signalent. Méthodes : Pour ce faire, nous avons effectué un sondage transversal auquel ont participé des athlètes $(\mathrm{n}=225)$ pratiquant plusieurs sports différents. Fait à noter, ces athlètes étaient issus de cinq écoles secondaires du Manitoba faisant partie de la même division. Résultats : Les participants à cette étude étaient bien conscients des signes, des symptômes et des conséquences des commotions cérébrales liées au sport. Les symptômes d'ordre cognitif et émotionnel sont toutefois apparus comme les conséquences les moins mentionnées. Rappelons que les commotions cérébrales liées au sport sont répandues dans tous les sports des écoles secondaires, et ce, peu importe que les athlètes soient des garçons ou des filles. Sur 225 répondants, 35,3\% d'entre eux ont affirmé avoir subi une commotion cérébrale dans le cadre de la pratique d'un sport; de plus, moins de la moitié $(45,5 \%)$ de ces jeunes ont fini par en signaler une. Lors de compétitions, 38,4\% d'entre eux ont délibérément choisi de ne rien signaler ; dans le cas de pratiques, ils ont été 33,8 \% à le faire. Deux obstacles importants à un signalement ont émergé de cette étude : éprouver de la gêne $(3,4 / 7)$ et trouver qu'il est difficile d'en faire un (3,5/7). Nos répondants se sont néanmoins largement rejoints (moyenne : 5,91/7 ; écart-type : 0,09) dans leur intention de signaler une commotion cérébrale s'ils devaient en être victimes dans le futur. Conclusions : Ces résultats suggèrent donc que les athlètes des écoles secondaires pourraient tirer parti de programmes d'éducation ciblant les commotions cérébrales subies dans le cadre d'un sport. Les entraîneurs et le personnel médical des équipes doivent ainsi être formés afin d'être à l'affût, tant lors de compétitions que de pratiques, des signes et des symptômes liés à ces traumatismes. Enfin, cette étude entend aussi se pencher sur la mise en œuvre d'une loi en cours de préparation au Manitoba et peut-être aussi sur d'autres lois ailleurs au Canada.

Keywords: Concussion, High school, Awareness, Reporting

doi:10.1017/cjn.2019.58

Can J Neurol Sci. 2019; 46: 443-450

\section{INTRODUCTION}

Sport-related concussions (SRCs) have been at the forefront of sport medical concerns at all levels of sport. Concerns are especially focused on children aged 10-19 given their high prevalence of concussions ${ }^{1}$ and considering the importance of this time period with respect to brain development. ${ }^{2}$ The increasing awareness of chronic traumatic encephalopathy (CTE) has added to the concern about the long-term

From the Department of Kinesiology and Applied Health, The University of Winnipeg, Winnipeg, Canada.

Received February 22, 2019. Final Revisions Submitted March 27, 2019. Date of Acceptance April 18, 2019.

Correspondence to: Glen L. Bergeron, Department of Kinesiology and Applied Health, The University of Winnipeg, Winnipeg, Canada. Email: g.bergeron@uwinnipeg.ca 
implications on quality of life in later years. Alosco et al. ${ }^{3}$ reported on 211 tackle football players who donated their brains and determined that the onset of CTE symptoms increased 2.44 years earlier for every year before the age of 12 that the individual started playing football. Although the signs were deemed to be mild, 3 of 14 (21\%) high school football players tested positive for CTE at autopsy. ${ }^{4}$

The Center for Disease Control (CDC) reported 2.8 million traumatic brain injury (TBI)-related US emergency department (ED) visits in 2013. The rate of ED visits for sport-and-recreation (SR)-related injuries more than doubled among children 19 years and younger between 2001 and 2012. ${ }^{1}$ Zhang et al. ${ }^{5}$ reported on insurance-based data that included $8,828,248$ patients of which 43,884 patients were diagnosed with a concussion between 2007 and 2014. Youth, aged 15-19 years, had the highest incidence (16.5/1000 patients), followed by those 10-14 years $(10.5 / 1000$ patients), 20-24 years (5.2/1000 patients), and 5-9 years (3.5/ 1000 patients). During that 7 -year span, there was a $60 \%$ increase in concussions.

According to the Canadian Hospitals Injury Reporting and Prevention Program (CHIRPP), the prevalence of concussions from 2011 to 2016 was $12 \%$ of all sport-related injuries. Of those, males 15-19 years incurred the most concussions reportedly in rugby $(22.7 \%)$, ice hockey $(20.2 \%)$, football $(17.4 \%)$, and basketball $(10.4 \%)$. Conversely, concussions in female athletes 1519 years in this same time period represented $18 \%$ of all injuries including ringette $(44.37 \%)$, ice hockey $(36.6 \%)$, rugby $(27.7 \%)$, and basketball $(17.7 \%){ }^{6}$

Harris et al. ${ }^{2}$ reported on SR-based head injuries (HI) from five hospitals in the Edmonton region from 1995 to 2007. Of the 63,219 SR-related injuries recorded, 4935 (7.8\%) were HI. Patients less than 18 years of age sustained $69.8 \%$ of all SR head injuries.

In 2016-2017 alone, 46,000 concussions were diagnosed in Canadian hospital EDs for children aged 5-19. Ice hockey, rugby, and ringette accounted for the most concussions (ranging from $27 \%$ to $44 \%$ ). Males accounted for more concussions (54\%) than females $(45 \%){ }^{8}$

In 2016, the Federal, Provincial and Territorial (F-P/T) Ministers responsible for sport, physical activity, and recreation acknowledged that concussions were an important public health issue. The federal government committed 1.4 million dollars over 2 years to develop a national strategy to prevent and treat SRCs. ${ }^{7}$

\section{High School Concussion Rates}

There is very little data regarding the prevalence of concussions in high school sports. Register-Mihalik ${ }^{8}$ reported that $53.3 \%$ of surveyed participants reported having sustained at least one SRC. ${ }^{12}$ McCrae et al. ${ }^{9}$ reported that of 1532 varsity football players from 20 US high schools, $29.9 \%$ reported a previous history of concussion and $15.3 \%$ reported sustaining a concussion during the current football season. Gessel et al. ${ }^{10}$ reported that $8.9 \%$ or $396 / 4431$ high school athletic injuries in 2005-2006 were diagnosed as concussions. Marar et al. ${ }^{11}$ reported on 1936 concussions in athletes also from 20 US high school sports over a 2 -year period. The authors reported a rate of 2.5 per 10,000 athlete exposures (AEs). The injury rate was greater during competition (6.4). Only Pakzad-Vaezi and Singhal ${ }^{12}$ reported on Canadian, albeit indirect school data. The authors reported that
$29.6 \%$ of the 27,466 SR activity injuries reported at the Vancouver Children's Hospital between 1992 and 2005 occurred at school. In this same timeframe, head injuries represented $11.3 \%$ of all injuries and $20.6 \%$ of all admissions to hospital.

\section{Unreported Injuries}

As concerning as the prevalence of concussions may be, concussions are deemed to be underreported. ${ }^{13}$ As many as $50 \%$ of concussions go unreported. ${ }^{8,13-15}$ Most studies are based on concussions reported to EDs. ${ }^{16}$ Concussions that may not be captured in the data include those who report to their family physician, athletic therapist, or walk in clinic and so on. Kerr ${ }^{15}$ reported that football players were least likely to report a concussion $(68.3 \%)$ and males were least likely to report than females. Meehan ${ }^{13}$ suggests that trained observer data are significantly higher than self-reported data. McGuine ${ }^{17}$ determined that the reporting of concussions increases from schools with low- to medium- to high-level access of on-site athletic trainers. Only $50 \%$ of those athletes with low access to an athletic trainer followed a return to play protocol. $\mathrm{McCrea}^{15}$ reported that the most common reason for not reporting was lack of awareness of the seriousness of a concussion $(66.4 \%)$ followed by fear of being withdrawn from participation $(41 \%)$ and unable to recognize a concussion $(36.1 \%)$.

Research indicates that concussion education may have an effect on the reporting rate. ${ }^{18-20}$ Taylor $^{18}$ conducted a systematic review of four studies, three of which demonstrated an association between education and increase reporting of concussions. In a study of Korean athletes, Lee et al. ${ }^{21}$ reported that, of the $8.9 \%$ of participants who reported having sustained a concussion, only approximately $50 \%$ reported the incident. ${ }^{27}$

Education also affects the athlete's decision to return to play. Kurowski $^{20}$ reported that there was a significantly lower proportion of athletes who continued to play despite having symptoms of concussion in those schools with concussion education (72\%) compared to students who did not receive concussion education (78\%). In the Korean high school study, $63.9 \%$ of the athletes who reported SRC symptoms made their own return to play decisions. $^{21}$ Eagles $^{22}$ reported that although concussion knowledge was maintained over time, attitudes did not change from baseline. Kroshus ${ }^{28}$ reported that SRC education resulted in an increase in athlete intention to encourage teammates to report a concussion but no effect on their intention to report their suspicions to a coach or athletic trainer.

The purpose of this research was to determine the incidence of concussions in Canadian high school sport, athlete knowledge of the signs, symptoms and consequences of SRC, and how likely student athletes are to report a concussion.

\section{Methods \\ Research Design}

A cross-sectional survey of athletes from five high schools in a single school division in the Winnipeg area was administered between December 2015 and May 2016. All athletes who competed in all high school sanctioned sports were invited to participate. A survey questionnaire was explained using a prescribed script and administered in a group setting by two research assistants at each school. The survey collected information on their concussion 
history, knowledge of concussions, and attitude toward reporting a concussion. Ethics approval was granted by the University of Winnipeg Human Research Ethics Board (UHREB).

\section{Survey Instrument}

The survey was a modified version of that validated by Register-Mihalik. ${ }^{14}$ Based on discussion with the author, amendments were made to some questions including a revised list of sports to coincide with Canadian high school sports. Questions 110 collected demographic information including their sport participation and if they ever received education about concussions. Questions 11-25 determined the level of knowledge regarding concussions. Questions 26-29 investigated the athlete's attitude toward concussion specifically looking at their attitude toward returning to play with a concussion. The signs and symptoms as listed on the SCAT 5 were included in the survey as were four false statements to serve as distractors (chest pain, skin rash, bleeding nose, and black eye). Questions 30-39 formed the second section of the survey, and specifically focused on those athletes who sustained an SRC while in high school. This section began by defining a concussion and its symptoms followed by questions to determine the incidence of concussions in sport and practices. The remaining questions collected information related to the rate of reporting and the attitudes and barriers that may have an effect.

\section{Procedure}

Approval from the school division was obtained. The physical education supervisor for the school division coordinated contact personnel in each school. The most convenient date and time was arranged with each contact person. Letters to the parents with attached athlete assent and parent consent forms were sent to the school contact person for distribution. Participation was completely voluntary. The survey was administered in paper form to athletes as a group at each high school at a predetermined date and time. Each student submitted a signed athlete assent and parental consent form prior to commencement of the survey. The research assistant provided prescripted directions to ensure consistency between schools. The students were informed to complete the first section of the survey and notify the research assistant when it was completed. Research assistants were available to answer any specific questions restricted to the logistics of the questionnaire. The first completed section was collected before the athlete continued with the second section of the survey. The survey required approximately 20 minutes to complete. Responses from the questionnaires were logged into an excel spreadsheet formatted to quantify the data.

\section{Analysis}

General descriptive statistics were used to examine the incidence of concussions, athlete knowledge and attitude scores, and concussion-reporting behaviors.

\section{Results}

A total of 225 athletes agreed to participate including 127 (56.7\%) males and 97 females (43.3\%). One individual did not respond to the gender question. The mean age was 15.5 years \pm 1 . Athletes who participated in high school sanctioned sport

\section{Table 1. Athlete demographics}

\begin{tabular}{|c|c|}
\hline Age (years) $N=224 *$ & Frequency $(\%)$ \\
\hline 14 & $51(22.8)$ \\
\hline 15 & $68(30.4)$ \\
\hline 16 & $57(25.4)$ \\
\hline 17 & $43(19.2)$ \\
\hline 18 & $5(2.2)$ \\
\hline 19 & $0(0)$ \\
\hline Mean age (STD) & $15.5(1.1)$ \\
\hline Gender $N=224 *$ & Frequency $(\%)$ \\
\hline Male & $127(56.7)$ \\
\hline Female & $97(43.3)$ \\
\hline Ethnicity. $N=197$ & Frequency $(\%)$ \\
\hline Arab & $1(1)$ \\
\hline Black & $18(9)$ \\
\hline Chinese & $1(1)$ \\
\hline Filipino & $25(13)$ \\
\hline First Nations, Métis, Inuit & $13(7)$ \\
\hline Japanese & $3(2)$ \\
\hline Korean & $1(1)$ \\
\hline Latin American & $2(1)$ \\
\hline South Asian & $10(5)$ \\
\hline Southeast Asian & $0(0)$ \\
\hline West Asian & $0(0)$ \\
\hline White & $143(73)$ \\
\hline Primary Sport $N=221$ & Frequency $(\%)$ \\
\hline Football & 44 (19.9) \\
\hline Hockey & $41(18.6)$ \\
\hline Soccer & $18(8.1)$ \\
\hline Basketball & $47(21.3)$ \\
\hline Volleyball & $65(29.4)$ \\
\hline Lacrosse & $0(0)$ \\
\hline Track \& Field & $4(1.8)$ \\
\hline Field hockey & $1(0.5)$ \\
\hline Sport level $N=222$ & Frequency $(\%)$ \\
\hline Junior varsity & $104(46.8)$ \\
\hline Varsity & 118 \\
\hline
\end{tabular}

*One person did not respond.

including football (19.9\%), hockey (18.6\%), soccer $(8.1 \%)$, basketball $(21.3 \%)$, volleyball $(29.4 \%)$, lacrosse $(0 \%)$, track \& field $(1.8 \%)$, and field hockey $(0.5 \%)$ were included in the study. Students were distributed across all four grades including grades $9(27 . \%), 10(33.3 \%), 11(22.7 \%)$, and $12(16.9 \%)$. Varsity and Junior varsity athletes accounted for $53.2 \%$ and $46 \%$ of the total participants, respectively. Table 1 outlines the subject demographics. Participation per school was distributed accordingly (names of schools have been deleted for confidentiality): high school 1 (34.2\%), 2 (15.6\%), 3 (16\%), 4 (14.7\%), and 5 (19.6\%). 
Table 2: Athlete source of concussion information

\begin{tabular}{l|c}
\hline Education & \% Yes (\% No) \\
\hline Discussed & $69.8(30.2)$ \\
\hline Athletic therapist & $21.8(78.2)$ \\
\hline Doctor & $30.7(69.3)$ \\
\hline Coach & $44.9(55.1)$ \\
\hline Parent & $48(52)$ \\
\hline
\end{tabular}

\section{Table 3: Reported concussions}

\begin{tabular}{|c|c|}
\hline Concussions - all $N=221$ & Frequency $(\%)$ \\
\hline 0 & $134(59.8)$ \\
\hline 1 & 49 (21.9) \\
\hline 2 & $19(8.5)$ \\
\hline 3 & $11(4.9)$ \\
\hline 4 & $4(1.8)$ \\
\hline 5 & $5(2.2)$ \\
\hline 6 & $1(0.4)$ \\
\hline 7 & $0(0)$ \\
\hline 8 & $0(0)$ \\
\hline 9 & $1(0.4)$ \\
\hline Total $\%$ concussions - all & 40.2 \\
\hline Concussions in sport $N=221$ & Frequency $(\%)$ \\
\hline 0 & $143(64.7)$ \\
\hline 1 & 48 (21.7) \\
\hline 2 & $15(6.8)$ \\
\hline 3 & $8(3.6)$ \\
\hline 4 & $3(1.4)$ \\
\hline 5 & $2(0.9)$ \\
\hline 6 & $1(0.5)$ \\
\hline 7 & $0(0)$ \\
\hline 8 & $0(0)$ \\
\hline 9 & $1(0.5)$ \\
\hline
\end{tabular}

Total \% concussions in sport 35.3.

Almost $70 \%$ (68.9) of the participants had some education about what constitutes a concussion or what to do in the event of a concussion (Table 2). Of those who reported having received this education, coaches (44.9\%) and parents (48\%) were most often the source of information. Physicians and athletic therapists were consulted by $30.7 \%$ and $21.8 \%$ of respondents, respectively. The latter likely reflects the fact that physicians and athletic therapists are not easily available to high school athletes. Of the 225 respondents, $40.2 \%$ (90) reported having sustained at least one concussion from all activities including sport. Seventy-eight $(35.3 \%)$ of the respondents reported having sustained an SRC (Table 3).
Table 4: Athlete knowledge items

\begin{tabular}{|c|c|}
\hline Athlete Knowledge & \\
\hline \multicolumn{2}{|c|}{$\begin{array}{l}\text { Please indicate which of the following you would consider a sign or symptom o } \\
\text { concussion. }\end{array}$} \\
\hline \multicolumn{2}{|l|}{ (Select all that apply) $N=225$} \\
\hline Knowledge items & Frequency Correct Responses (\%) \\
\hline Headache (true) & $211(94)$ \\
\hline Dizziness (true) & $206(92)$ \\
\hline Sensitivity to light (true) & $179(80)$ \\
\hline Confusion (true) & $174(77)$ \\
\hline Balance problems (true) & $172(76)$ \\
\hline Blurred vision (true) & $170(76)$ \\
\hline "Pressure in head" (true) & $169(75)$ \\
\hline Difficulty concentrating (true) & $165(73)$ \\
\hline Difficulty remembering (true) & $161(72)$ \\
\hline Nausea or vomiting (true) & $145(64)$ \\
\hline Sensitivity to noise (true) & $144(64)$ \\
\hline Drowsiness (true) & $138(61)$ \\
\hline "Don't feel right" (true) & $132(59)$ \\
\hline Fatigue or low energy (true) & $123(55)$ \\
\hline Feeling slowed down (true) & $101(45)$ \\
\hline Feeling like "in a fog" (true) & $99(44)$ \\
\hline Neck pain (true) & $88(39)$ \\
\hline Trouble falling asleep (true) & $76(34)$ \\
\hline Nervous or anxious (true) & $64(28)$ \\
\hline Irritability (true) & $61(27)$ \\
\hline Bleeding from the nose (false) & $49(22)$ \\
\hline Sadness (true) & $42(19)$ \\
\hline More emotional (true) & $41(18)$ \\
\hline Black eye (false) & $18(8)$ \\
\hline Chest pain (false) & $8(4)$ \\
\hline Skin rash (false) & $6(3)$ \\
\hline
\end{tabular}

The knowledge items which had $60 \%$ or more positive responses were primarily physical and cognitive in nature. Concussion signs and symptoms recognized less than $60 \%$ of the time were more "feeling" and emotional in nature (Table 4). High school students are less likely to relate "feeling" issues as a consequence of a concussion including not feeling right (59\%), fatigue or low energy (55\%), feeling slowed down (45\%), and feeling like in a fog (44\%). Emotional issues were even less likely to be associated with a concussion including being nervous or anxious $(28 \%)$, being irritable (27\%), sadness (19\%), and more emotional (18\%). Interestingly, neck pain $(39 \%)$ and trouble falling asleep (34\%) were also not commonly associated with concussions. For the most part, respondents were less likely to identify those symptoms that were not commonly associated with a concussion including bleeding from the nose $(22 \%)$, black eye $(18 \%)$, chest pain $(4 \%)$, and skin rashes $(3 \%)$. 


\section{Table 5: General athlete knowledge items}

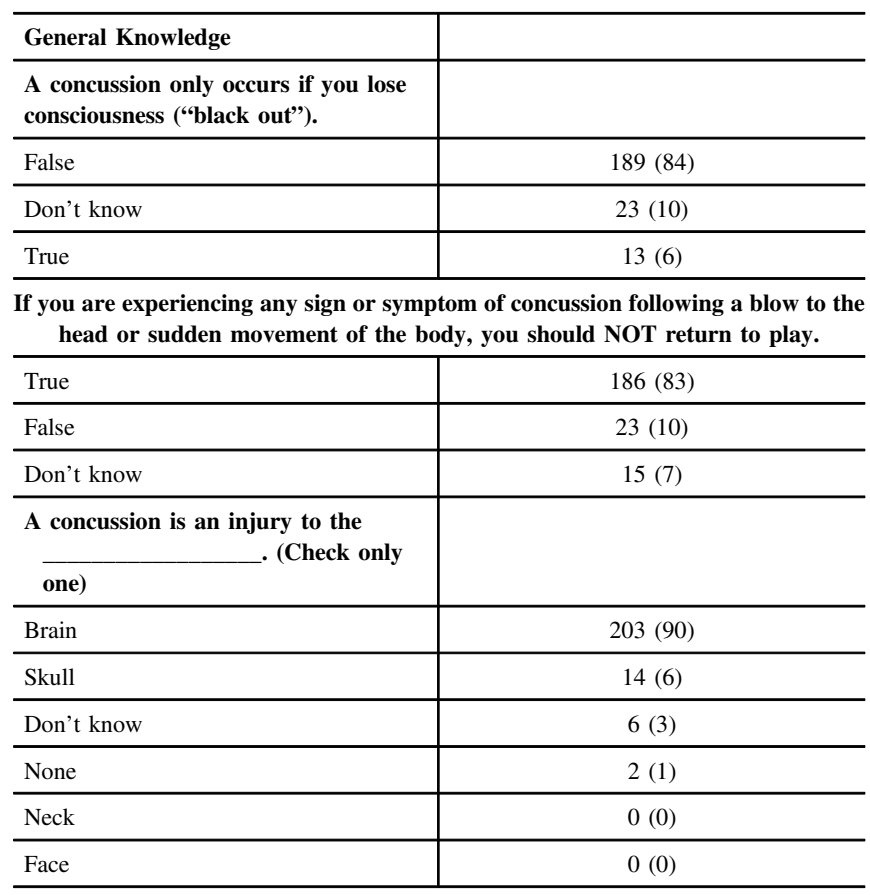

Multiple concussions: of the following, what are possible complications of having multiple concussions?

\begin{tabular}{l|c}
\hline Brain damage & $205(91)$ \\
\hline Memory problems & $181(80)$ \\
\hline Increased risk of further injury & $163(72)$ \\
\hline Trouble in school & $125(56)$ \\
\hline Being more emotional & $45(20)$ \\
\hline I don't know & $10(4)$ \\
\hline No complications exist & $2(1)$ \\
\hline
\end{tabular}

Returning to play too soon: Of the following, what are possible complications of returning to sporting activity while still experiencing possible concussion symptoms? (Check all that apply)

\begin{tabular}{l|c}
\hline Increased risk of further injury & $193(86)$ \\
\hline Brain damage & $189(84)$ \\
\hline Paralysis & $86(38)$ \\
\hline I don't know & $22(10)$ \\
\hline None & $3(1)$ \\
\hline Skin rash & $1(0.4)$ \\
\hline
\end{tabular}

With respect to general knowledge (Table 5), most participants were aware that sustaining a concussion was not dependent on loss of consciousness (84\%). Most (83\%) were aware that one should not return to play when experiencing any signs or symptoms of concussion. Similarly, most respondents were aware that a concussion was an injury to the brain (90\%) as opposed to the skull $(6 \%)$.

Most respondents recognized that brain damage (91\%) and memory problems $(80 \%)$ were possible complications of multiple concussions. Fewer $(72 \%)$ were aware of the risk of further injury
Table 6: Athlete attitude

\begin{tabular}{l|c}
\hline Rate on a Scale of 1-7 & Mean (SD) \\
\hline $\begin{array}{l}\text { How serious you think it is when you } \\
\text { experience a headache and dizziness } \\
\text { following a blow to the head or body. }\end{array}$ & $5.0(1.36)$ \\
\hline $\begin{array}{l}\text { How important you think it is, not to } \\
\text { participate in physical activity (game or } \\
\text { practice) when experiencing signs and } \\
\text { symptoms of concussion. }\end{array}$ & $5.9(1.23)$ \\
\hline $\begin{array}{l}\text { How important you think it is to be } \\
\text { informed about how concussions } \\
\text { happen. }\end{array}$ & $6.1(1.18)$ \\
\hline $\begin{array}{l}\text { How important you think it is to be } \\
\text { informed about how concussions can be } \\
\text { prevented }\end{array}$ & $6.1(1.21)$ \\
\hline $\begin{array}{l}\text { How important you think it is to be } \\
\text { informed about what to do if you have a } \\
\text { concussion. }\end{array}$ & \\
\hline $\begin{array}{l}\text { How important you think it is to report } \\
\text { possible concussion symptoms to a } \\
\text { medical professional (doctor, athletic } \\
\text { trainer, etc) or your coach }\end{array}$ & $6.5(0.87)$ \\
\hline $\begin{array}{l}\text { In general, athletes are under-educated } \\
\text { (don't know enough) about } \\
\text { concussions. }\end{array}$ & \\
\hline
\end{tabular}

'FOR ME TO REPORT POSSIBLE CONCUSSION SYMPTOMS TO A COACH OR A MEDICAL PROFESSIONAL WHEN I EXPERIENCE THEM WOULD BE......' Rate on a scale of $1-7$

\begin{tabular}{l|c}
\hline & Mean (SD) \\
\hline Cowardly/Brave & $5.3(1.34)$ \\
\hline Pleasant/Embarrassing* & $3.4(1.60)$ \\
\hline Harmful/Beneficial & $6.1(1,11)$ \\
\hline Extremely easy/Extremely difficult* & $3.5(1.86)$ \\
\hline Good/Bad* & $2.1(1.52)$ \\
\hline Worthless/Valuable & $5.8(1, .45)$ \\
\hline
\end{tabular}

*These indicate reverse values where a low score is more indicative of a positive attitude.

(such as second impact syndrome). Trouble in school was associated as a complication of multiple concussions by only $56 \%$ of respondents. Once again, only $20 \%$ of participants recognized the effect of multiple concussions on emotional health.

Respondents were aware that early return to play before full recovery could result in an increase in further injury (86\%) and further brain damage (84\%). The increased chance of paralysis was deemed to be a possibility by only $38 \%$ of respondents.

Respondent attitude toward concussion is generally positive and in support of getting more information about concussions and the importance of reporting a concussion to a coach or medical personnel. Similarly, there was a generally positive attitude with regard to how they would feel about reporting the signs and symptoms of a concussion in a game or practice situation. The only two notable feelings are feelings of difficulty to report (3.5/7) and feelings of embarrassment (3.4/7) (Table 6). 
Table 7: Continued to play in game or practice with symptoms

\begin{tabular}{l|c|c}
\hline Yes/No & Game $\boldsymbol{N = 2 2 4}$ & Practice $\boldsymbol{N = 2 2 5}$ \\
\hline Yes & 138 & 149 \\
\hline No & 86 & 76 \\
\hline$\%$ yes & 38.4 & 33.8 \\
\hline
\end{tabular}

Table 8: Barriers to reporting a concussion

\begin{tabular}{|c|c|}
\hline & Yes $(\%)$ \\
\hline N/A - I would report it & $78(35.3)$ \\
\hline $\begin{array}{l}\text { Would not think it was serious enough to } \\
\text { report }\end{array}$ & $41(45.6)$ \\
\hline $\begin{array}{l}\text { Would not want to let your teammates } \\
\text { down }\end{array}$ & $21(23.3)$ \\
\hline Would not want to let your coaches down & $18(20)$ \\
\hline $\begin{array}{l}\text { Would not know at the time it was a } \\
\text { concussion }\end{array}$ & $29(32.2)$ \\
\hline $\begin{array}{l}\text { Would not want to be removed from a } \\
\text { practice }\end{array}$ & $15(16.7)$ \\
\hline $\begin{array}{l}\text { Would not want to be removed from the } \\
\text { game }\end{array}$ & $29(32.2)$ \\
\hline
\end{tabular}

Even though there is general agreement that concussions should be reported, $38.4 \%$ of all respondents indicated having continued play with signs and symptoms of a concussion incurred during a game situation and $33.8 \%$ during practice (Table 7). In contrast, most respondents indicated that they would report their concussion to a medical professional or coach $(N=222$, Mean 5.9/7, SD 1.4). In keeping with these results, when asked what reasons would lead them to not report a concussion, $35.3 \%$ of respondents indicated they would report the concussion regardless. Notably, $45.6 \%$ of respondents would not report a concussion thinking the concussion was not serious enough. Approximately one-third $(32.2 \%)$ of respondents may not report a concussion because they would not know it was a concussion or they would not want to be removed from the game. There was strong agreement (Mean 5.91/7, SD 0.09) when asked if they intend to report a concussion should they experience one in the future (Table 8).

As indicated in the procedures, once respondents completed the first section of the questionnaire, they were given the second portion of the survey. This section began by first outlining the signs and symptoms of a concussion and focused on collecting data specifically from athletes who sustained an SRC in a game or practice situation.
Table 9: Athlete report of concussion post definition during games

\begin{tabular}{l|c|c|c}
\hline $\begin{array}{l}\text { No. of } \\
\text { Concussions }\end{array}$ & $\begin{array}{c}\text { Total } \\
\text { Rrespondents } \\
\boldsymbol{N = 2 2 3}\end{array}$ & $\begin{array}{c}\text { Total Concussions } \\
(\mathbf{\%})\end{array}$ & Total Reported \\
\hline 1 & 43 & $43(27.6)$ & 59 \\
\hline 2 & 5 & $10(6.4)$ & 5 \\
\hline 3 & 13 & $39(25.0)$ & 3 \\
\hline 4 & 5 & $20(12.8)$ & 2 \\
\hline 5 & 4 & $20(12.8)$ & 2 \\
\hline 6 & 1 & $6(3.8)$ & \\
\hline 7 & 0 & $0(0)$ & \\
\hline 8 & 1 & $8(5.1)$ & \\
\hline 9 & 0 & $0(0)$ & \\
\hline 10 & 1 & $10(6.4)$ & \\
\hline Total & 73 & 156 & 71 \\
\hline$\%$ & 32.7 & 100 & 45.5 \\
\hline
\end{tabular}

Table 10: Reported concussions in a practice situation

\begin{tabular}{l|c|c|c}
\hline $\begin{array}{l}\text { No. of } \\
\text { Concussions }\end{array}$ & $\begin{array}{c}\text { Total } \\
\text { Respondents } \\
\boldsymbol{N = 2 1 4}\end{array}$ & $\begin{array}{c}\text { Total Concussions } \\
(\boldsymbol{\%})\end{array}$ & Total Reported \\
\hline 1 & 23 & $23(23.2)$ & 39 \\
\hline 2 & 10 & $20(20.2)$ & 3 \\
\hline 3 & 6 & $18(18.2)$ & 1 \\
\hline 4 & 3 & $12(12.1)$ & 1 \\
\hline 5 & 2 & $10(10.1)$ & 1 \\
\hline 6 & 1 & $6(6.1)$ & \\
\hline 7 & 0 & $0(0)$ & 45 \\
\hline 8 & 0 & $0(0)$ & 45.5 \\
\hline 9 & 0 & $0(0)$ & \\
\hline 10 & 1 & $10(10.1)$ & \\
\hline Total & 46 & 99 & \\
\hline$\%$ & 21.4 & & \\
\hline
\end{tabular}

\section{USE THE FOLLOWING DEFINITION TO ANSWER THE QUESTIONS IN THIS SECTION (SECTION 2)}

A concussion is an injury caused by a blow to the head or sudden movement of the body followed by a variety of signs and symptoms that may include any of the following: headache, dizziness, loss of balance, blurred vision, "seeing stars", feeling in a fog or slowed down, memory problems, poor concentration, nausea, or throwing up. Getting "knocked out" or being unconscious does NOT always occur with a concussion. 
Using this definition of a concussion, respondents were once again asked to report on the number of concussions they sustained during their high school years in either games or practices. In this case, $73(32.7 \%)$ of all respondents reported having sustained a total of 156 concussions during a game. Of the total game-related concussions, 71/156 (45.5\%) were reported to a medical professional or coach (Table 9). Only 45/99 (45.5\%) of concussions incurred during practice were reported (Table 10).

Of those respondents who indicated having chosen not to report at least one concussion, $52 \%$ did not think it was serious enough to report, $31.5 \%$ would not want to let their teammates down, $26.8 \%$ did not want to let their coaches down, $37.0 \%$ did not know at the time it was a concussion, $25.2 \%$ did not want to be removed from a practice, and $45.7 \%$ did not want to be removed from the game. The perceived feelings toward reporting a concussion were similar in those who indicated not having reported a concussion and the feelings of all respondents. Being embarrassed (3.1/7, SD 1.31) and extremely difficult (3.1/7 SD 1.71) were the most notable concerning feelings expressed.

\section{Discussion}

There are a number of interesting insights from this study. The rate of reported concussions in this study coincided with that reported by some studies, ${ }^{5,6,14}$ but higher than that reported in some studies. ${ }^{7,9,10,12,23}$ The fact that $40.2 \%$ of high school athletes in this study reported an SRC points to the need for a concerted preventative effort. The Federal Government of Canada allocated 1.4 million dollars to a concussion strategy based on the fact that $39 \%$ of children and youth $10-18$ years who visit an ED in Canada were diagnosed with a concussion. A further $24 \%$ were designated possible concussions. Most athletes in the study were well versed on the physical signs and symptoms of a concussion but less so on the cognitive and emotional symptoms. Lee et al. ${ }^{21}$ reported that none of the Korean athletes surveyed were able to identify all of the nine SRC signs and symptoms. Given the close relationship an athlete has with their peers, it is important that they are able to identify and relate changes in mood and personality to a concussion so that a concussion is reported early, properly identified, and managed. The primary source of education was from parents and coaches and less so from physicians and athletic therapists. This would suggest the importance of educating parents and coaches.

Athletes are still choosing to return to practice and games even though they are experiencing signs and symptoms of concussion. Wanting to remain in the game seems to be a major motivator for not reporting symptoms. Being embarrassed in front of their friends appears to contribute to the difficulty athletes experience when it comes to reporting a concussion. A lack of knowledge regarding the signs, symptoms, and/or an inability to recognize a concussion may contribute to the lack of reporting. Studies have acknowledged the positive impact of education on reporting. ${ }^{18,19,21}$

There is some suggestion that athletes should not participate in tackle football until the age of 18 to account for the degree and importance of brain development occurring before then. There may be room for further investigation in the high school athlete's capacity to project forward the potential longterm consequences of severe or repetitive concussions and decisions to hide symptoms and return to play when still symptomatic.

Canadian high school athletes, in particular, are of interest given that they are not normally supported by medical personnel as a regular part of their team. Pryor reported that $70 \%$ of US high schools offer on-site athletic training services. ${ }^{24}$ Only $37 \%$ of the athletic trainers in this study are full time. This limits comprehensive coverage for games and practices. Only one private high school in Manitoba hires a full-time athletic therapist. The Manitoba High School Football Association hires certified athletic therapists to be on-site for high school football games. Future consideration should be given to including athletic therapists either full or part time as part of the teaching faculty in Manitoba high schools.

Governments in Canada are increasingly becoming more aware of the impact of SRCs in youth. ${ }^{6,7,25-27}$ A national strategy is being funded by the Federal government and the Province of Ontario as enacted the Rowan's Law. Manitoba has tabled similar legislation that calls for more education and medical oversight to prevent and manage concussions. Insights to the incidence, awareness, and reporting tendencies of high school athletes will better inform the implementation of the law when it is enacted in Manitoba.

\section{Conclusions}

The prevalence of SRCs in Manitoba high schools warrants more attention. Educating athletes regarding the signs and symptoms especially the cognitive and emotional symptoms may reduce the prevalence of returning to play with concussion symptoms or the lack of reporting to medical professionals or coaches. Coaches and attending medical professionals should be aware of the predisposition to hide the symptoms. More than half of the concussions in this study went unreported in both game and practice situations. Athletes need to be better educated regarding the importance of reporting. Coaches and team medical staff must be trained to be vigilant for the mechanism, signs, and symptoms of injury in both game and practice situations. The Manitoba Concussion Youth $\mathrm{Act}^{27}$ proposes to require a medical assessment by a physician or nurse practitioner for all youth who sustain a concussion. This will provide the opportunity to educate the athlete on the pathological process of recovery, the importance of full recovery, and future preventative strategies. Return to play protocols should be emphasized to prevent early return while still symptomatic. The stigma associated with concussions should be addressed with athletes to overcome the embarrassing feelings that negatively affect the propensity to report a concussion.

\section{Disclosures}

The author has no conflicts of interest to declare.

\section{ACKNOWLedgements}

The author would like to acknowledge the contributions of Jessica Thomas, Pamela Ryczko and Ashley Phommarath for 
their assistance in conducting the pilot questionnaire, athlete surveys and data collection.

\section{REFERENCES}

1. Centers for Disease C. Brain injury and concussion. Available at: https://www-cdc-gov.uwinnipeg.idm.oclc.org/traumaticbraininjury/get_the_facts.html; accessed January 11, 2018.

2. Harris AW, Jones CA, Rowe BH, Voaklander DC. A populationbased study of sport and recreation-related head injuries treated in a Canadian health region. J Sci Med Sport. 2011;15(4):298-304.

3. Alosco ML, Mez J, Tripodis Y, et al. Age of first exposure to tackle football and chronic traumatic encephalopathy. Ann Neurol. 2018;83(5):886-901.

4. Mez J, Daneshvar DH, Kiernan PT, et al. Clinicopathological evaluation of chronic traumatic encephalopathy in players of American football. JAMA. 2017;318(4):360-70.

5. Zhang AL, Sing DC, Rugg CM, Feeley BT, Senter C. The rise of concussions in the adolescent population. Orthop J Sports Med. 2016;4(8):2325967116662458.

6. Bryan MA, Rowhani-Rahbar A, Comstock RD, Rivara F. Sportsand recreation-related concussions in US youth. Pediatrics. 2016;138(1):e20154635.

7. Government of Canada Public Health Association of Canada. Sport and recreation-related concussions and other traumatic brain injuries among Canada's children and youth. October 11, 2018. Available at: https://infobase.phac-aspc.gc.ca/datalab/headinjury-interactive-en.html; accessed May 10, 2019.

8. Register-Mihalik JK, Linnan LA, Marshall SW, McLeod TCV, Mueller FO, Guskiewicz KM. Using theory to understand high school aged athletes' intentions to report sport-related concussion: Implications for concussion education initiatives. Brain Injury. 2013;27(7-8):878-86.

9. McCrea M, Hammeke T, Olsen G, Leo P, Guskiewicz K. Unreported concussion in high school football players: implications for prevention. Clin J Sport Med. 2004;14(1):13-17.

10. Gessel LM, Fields SK, Collins CL, Dick RW, Comstock RD. Concussions among United States high school and collegiate athletes. J Athletic Training. 2007;42(4):495.

11. Marar M, Mcllvain NM, Fields SK, Comstock RD. Epidemiology of concussions among United States High School Athletes in 20 Sports. Am J Sports Med. 2012;40(4):747-55.

12. Pakzad-Vaezi K, Singhal A. Trends in paediatric sport- and recreation-related injuries: An injury surveillance study at the British Columbia Children's Hospital (Vancouver, British Columbia) from 1992 to 2005. Paediatr Child Health. 2011;16(4):217-21.

13. Meehan Iii WP, Bachur RC. Sport-related concussion. Pediatrics. 2009;123(1):114-23.
14. Register-Mihalik JK, Guskiewicz KM, McLeod TCV, Linnan LA, Mueller FO, Marshall SW. Knowledge, attitude, and concussionreporting behaviors among high school athletes: a preliminary study. J Athl Train. 2013;48(5):645-653.

15. Kerr ZY, Register-Mihalik JK, Kroshus E, Baugh CM, Marshall SW. Motivations associated with nondisclosure of self-reported concussions in former collegiate athletes. Am J Sports Med. 2016;44(1):220-25.

16. Caine DJ, Purcell LK. Injury in pediatric and adolescent sports: epidemiology, treatment, and prevention. Cham: Springer; 2016.

17. McGuine TA, Pfaller AY, Post EG, Hetzel SJ, Brooks A, Broglio SP. The influence of athletic trainers on the incidence and management of concussions in high school athletes. J Athletic Training. 2018.

18. Taylor ME, Sanner JE. The relationship between concussion knowledge and the High School Athlete's intention to report traumatic brain injury symptoms. J Sch Nurs. 2017;33(1):73-81.

19. Bramley H, Patrick K, Lehman E, Silvis M. High school soccer players with concussion education are more likely to notify their coach of a suspected concussion. Clin Pediatr. 2012;51(4): 332-36.

20. Kurowski BG, Pomerantz WJ, Schaiper C, Ho M, Gittelman MA. Impact of preseason concussion education on knowledge, attitudes, and behaviors of high school athletes. J Trauma Acute Care Surg. 2015;79(3):S28.

21. Lee HR, Resch JE, Han TK, Miles JD, Ferrara MS. Sport-related concussion knowledge and occurrence: a survey of High School and College Athletes in South Korea. Int J Athletic Ther Training. 2016;21(2):53-60.

22. Eagles ME, Bradbury-Squires DJ, Powell MF, Murphy JR, Campbell GD, Maroun FB. The impact of a concussion-U educational program on knowledge of and attitudes about concussion. Can J Neurol Sci. 2016;43(5):659-64.

23. Giannotti M, Al-Sahab B, McFaull S, Tamim H. Epidemiology of acute soccer injuries in Canadian children and youth. Pediatr Emerg Care. 2011;27(2):81-85.

24. Pryor RR, Casa DJ, Vandermark LW, et al. Athletic training services in public secondary schools: a benchmark study. J Athl Train. 2015;50(2):156-62.

25. Government of Canada. Concussion: Symptoms and treatment. Available at: https://www.canada.ca/en/public-health/services/ diseases/concussion-sign-symptoms.html; accessed April 9, 2016.

26. Rowan's Law (Concussion Act). Available at: https://www. ontario.ca/laws/statute/S18001; accessed January 11, 2018.

27. Manitoba Concussion in Youth Act. Available at: https:// web2.gov.mb.ca/bills/41-2/b037e.php; accessed January 11, 2018.

28. Kroshus E, Garnett BR, Baugh CM, Calzo JP. Engaging teammates in the promotion of concussion help seeking. Health Educ Behav. 2016;43(4):442-51. 